\title{
Effect of Solvents and Extraction Conditions on the Properties of Crude Rice Bran Oil
}

\author{
Benchamaporn PIMPA ${ }^{1, *}$, Chakree THONGRAUNG ${ }^{2}$ and Pornpong SUTTHIRAK ${ }^{3}$ \\ ${ }^{I}$ Faculty of Innovative Agriculture and Fishery Establishment Project, Prince of Songkla University, \\ Surat Thani 84000, Thailand \\ ${ }^{2}$ Faculty of Agro-Industry, Prince of Songkla University, Songkhla 90110, Thailand \\ ${ }^{3}$ Faculty of Science and Industrial Technology, Prince of Songkla University, Surat Thani 84000, Thailand
}

('Corresponding author's e-mail: benchamaporn.p@psu.ac.th)

Received: 5 March 2020, Revised: 5 April 2021, Accepted: 12 April 2021

\begin{abstract}
This research aimed to study the effect of solvents, namely $n$-hexane and ethanol, on the yield of crude rice bran oil extraction. The effects of extraction temperatures of 50,60 , and $70{ }^{\circ} \mathrm{C}$ and extraction times of $1,3,6,12$, and $24 \mathrm{~h}$ were investigated. Rice bran composition was determined. It was found that protein, lipid, moisture, fiber, ash, and carbohydrate content were $12.65 \pm 0.56,16.32 \pm 0.81,7.65 \pm 0.62$, $10.25 \pm 0.64,6.38 \pm 0.59$, and $46.75 \%$, respectively. From the results, the rice bran oil yield from $n$-hexane extraction was significantly higher than ethanol extraction, with $\mathrm{p}<0.05$. The maximum rice bran oil obtained from $n$-hexane extraction was $16.23 \pm 0.34 \%$. The highest yield of rice bran oil was obtained from extraction temperature of $60-70{ }^{\circ} \mathrm{C}$ for $12-24 \mathrm{~h}$. After extraction by the optimum conditions at 60 ${ }^{\circ} \mathrm{C}$ for $12 \mathrm{~h}$, the rice bran oil was kept for $1,2,3,4$, and 8 weeks for investigation of its quality changes. It can be concluded that the optimum conditions for rice bran oil extraction was with using $n$-hexane as a solvent for extraction at a temperature of $60^{\circ} \mathrm{C}$ for $12 \mathrm{~h}$. Storing oil for $0,1,2,4$, and 8 weeks resulted in the increase of free fatty acids (FFA) and peroxide value, whereas iodine value and saponification value were relatively constant.
\end{abstract}

Keywords: Rice bran, Rice bran oil, Extraction, Solvent, Extraction conditions

\section{Introduction}

Rice bran is a byproduct from rice milling plants and has been reported to have health-promoting effects [1,2]. Milling is an important step in the production of rice from paddy. The basic objective of a rice milling system is to remove the husk and bran layers and to produce white rice. The main byproducts of rice milling are rice straw, rice husk or hull, and rice bran. Rice bran is produced during the second stage in milling, viz., the whitening or polishing process, when the bran layer is removed from the brown rice kernel. One hundred $\mathrm{kg}$ of paddy rice will generate approximately $5-10 \mathrm{~kg}$ of bran. Rice bran is a mixture of substances, including protein, fat, ash, and crude fiber. In many cases, bran contains tiny fractions of rice hull, which increases the ash content of bran. Bran composition is largely dependent on the milling process. In modern rice mills, several different kinds of bran are produced; coarse bran (from the first whitening step), fine bran (from second whitening step) and polish (from the polishing step). Polish consists of part of the endosperm and is often referred to as meal. Rice bran has a high nutritive value. Besides proteins, rice bran is an excellent source of vitamins B and E. Bran also contains small amounts of antioxidants, which are used to lower cholesterol in humans. Rice bran contains $10-26 \%$ oil depending on the rice variety, milling process, and other agro-climatic conditions $[3,4]$. The oily nature 
makes bran an excellent binder for animal feeds. Rice bran oil, once stabilized and extracted, is made into a high-quality vegetable oil for cooking or eating. Rice bran is usually added to animal feeds as an ingredient, in particular in those for ruminants and poultry. In recent years, however, advances in stabilization techniques have been made, which have led to new uses for bran and its derivatives; most notably, bran oil for cooking, and waxes for cosmetic products. In developing countries, rice bran is underutilized, due to a lack of suitable stabilization techniques.

The extraction of rice bran results in rice bran oil as a byproduct. Rice bran needs to undergo a process called stabilization to render the enzymes inactive and inhibit lipid oxidation after the milling process, in order to prevent the deterioration of fat and valuable bioactive compounds [5]. Many stabilization methods have been reported in the literature, such as steaming, ohmic heating [5-7], ultrasound treatment [2,8], parboiling, refrigeration and $\mathrm{pH}$ lowering [9], and microwave radiation [10]. There are several techniques used for the extraction of rice bran oil, including solvent extraction using $n$-hexane, which is the most popular for commercial conventional extraction. The use of $n$-hexane in the conventional methods has some drawbacks, due to its flammability, toxicity, and the high temperatures involved in the process, resulting in some undesirable components in the oil as a result of oxidative deterioration, the development of rancidity, and an off-flavor. Efforts have been made by many researchers to explore different, nonconventional techniques for oil extraction and utilization. Some of these methods are supercritical carbon dioxide extraction, subcritical water extraction, and enzymeassisted extraction.

The objective of this work was to study the effect of solvents, namely $n$-hexane and ethanol, and the extraction conditions on the yield and properties of crude rice bran oil, as a basis for further study.

\section{Materials and methods}

\section{Raw material preparation}

The rice bran used in this study was a by-product obtained from milling of the Chiang Phatthalung rice, collected from a farmer in Phatthalung province, Thailand. The rice bran was later transported to a laboratory at the Laboratory and Equipment Center, Prince of Songkla University, Surat Thani campus. It was sieved and steamed at $115 \pm 2{ }^{\circ} \mathrm{C}$ for $15 \mathrm{~min}$, in order to minimize lipase activity, and then dried in a hot air oven at $50{ }^{\circ} \mathrm{C}$ for $30 \mathrm{~min}$. After that, it was sealed in a plastic bag and stored at $-20{ }^{\circ} \mathrm{C}$ for further processing. The chemical compositions of the collected rice bran samples, in terms of protein, lipid, moisture, fiber, and ash contents were determined according to the methods described by AOAC (1995) [11]. All reagents were of analytical grade.

\section{Determination of protein content}

The protein contents of the rice bran samples were estimated as percent total nitrogen by the Microkjeldahl procedure. Protein (\%) was calculated by multiplying the per cent nitrogen by the factor $6.25[11]$.

\section{Determination of moisture content}

The moisture contents were determined by drying $3 \mathrm{~g}$ of rice bran sample in a hot air oven, maintaining temperature at $105^{\circ} \mathrm{C}$, as per the procedure given in AOAC (1995) [11].

\section{Determination of ash content}

The ash contents of the samples were obtained by dry ashing the rice bran samples completely by heating it over a flame. This was expressed as $\mathrm{g} / 100 \mathrm{~g}$ of each sample [11].

\section{Determination of fat content}

Fat contents were estimated as crude ether extracts using moisture free samples. The solvent was removed by evaporation and the residue of fat was weighed [11]. Samples were carefully weighed to be 3 $\mathrm{g}$ and were put in paper sleeves paved with fat free cotton, then dried at $80{ }^{\circ} \mathrm{C}$ for about an hour. The dried samples were then placed in the dried and measurably weighed Soxhlet apparatus. Extraction with 
petroleum ether was done after $6 \mathrm{~h}$. Solvent was then purified by distillation, and the extracts was dried up at $105^{\circ} \mathrm{C}$ until constant.

Effect of extraction of solvents and extraction conditions on rice bran oil yield

The effect of using solvents, namely $n$-hexane and ethanol, to extract rice bran oil was studied. Rice bran was extracted by using Soxhlet apparatus at $60{ }^{\circ} \mathrm{C}$ for $1,3,6,12$, and $24 \mathrm{~h}$, respectively. Oil yield was determined by using the following equation;

Oil yield $(\%)=\frac{\text { Oil content of sample after extraction }(\mathrm{g}) \times 100}{\text { Weight of sample }(\mathrm{g})}$

Effect of storage time on quality of rice bran oil

The change in quality of the rice bran oil samples was evaluated by determining the FFA, peroxide value, iodine value, and saponification value. The samples were kept at room temperature for $0,1,4$, and 8 weeks. $50 \mathrm{~mL}$ of each sample was stored separately at room temperature in a glass bottle.

\section{Determination of free fatty acid (FFA)}

FFA was determined in rice bran oil according to the American Oil Chemists' Society (AOCS) Ca 5a-40 (1998) [12]. $3 \mathrm{~g}$ of rice bran oil sample was weighed in a $100 \mathrm{~mL}$ Erlenmeyer flask. It was then titrated with $0.1 \mathrm{~N} \mathrm{NaOH}$, and phenopthalein was used as an indicator.

\section{Determination of peroxide value}

A $0.1 \mathrm{~g}$ sample was weighed in a $100 \mathrm{~mL}$ Erlenmeyer flask. A solution of $5 \mathrm{~mL}$ of $3: 2$ acetic acid : chloroform and saturated KI solution were added and left for $1 \mathrm{~min}$. Then, $5 \mathrm{~mL}$ of distilled water was added before titration with $0.001 \mathrm{~N} \mathrm{Na}_{2} \mathrm{~S}_{2} \mathrm{O}_{3}$. A few drops of starch solution were added. The end point occurred when the blue color disappeared [11].

\section{Determination of iodine value}

Iodine value $\left(\mathrm{g} \mathrm{I}_{2} / 100 \mathrm{~g}\right)$ is determined in edible oils and fats according to Wij's method, as indicated by the AOAC Official Methods of Analysis (1995) [11]. Samples were dissolved in carbon tetrachloride $\left(\mathrm{CCl}_{4}\right) ; 25 \mathrm{~mL}$ of Wij's solution was added, and samples were kept in the dark for approximately $1 \mathrm{~h}$ to complete the reaction. Deionized water was added, and excess iodine was titrated with sodium thiosulphate.

\section{Statistical analysis}

The data obtained from the study were analyzed using analysis of variance (ANOVA) and the means were separated by Duncan's new multiple range test. The statistical analysis was computed by IBM SPSS Statistics.

\section{Results and discussion}

\section{Nutrient composition of rice bran}

Nutrient compositions of collected rice bran samples were determined and are shown in Table 1. Rice bran has a highly nutritious chemical composition. As a result, the protein content of rice bran was $12.65 \%$, which was lower than that obtained by Bhosale and Vijayalakshmi [13], with values of 17.50 and $19.25 \%$ for stabilized and probiotic treated rice bran, respectively. However, the protein content was found to be in the range of 12 - $17 \%$ reported by Saunders [14]. Due to the high protein content, rice bran is commonly used as a feed ingredient. Proteins play an important role in the formation of biomolecules rather than energy source. Lipid content is determined by direct extraction with a Soxhlet apparatus using nonpolar solvent (petroleum ether), based on the physical properties of substances with similar chemical characteristics dissolving in each other. Specifically, non-polar solvents tend to dissolve in non-polar solutes. By using this method, the measured level of lipid in bran amounted to $16.32 \%$; this value was 
relatively similar to that obtained by Bhosale and Vijayalakshmi [13], with values of $13.10 \%$ and 17.20 $\%$ for stabilized and probiotic treated rice bran, respectively.

To prevent the growth of microorganisms, while prolonging sample stability, samples must be dried in a hot air oven at $50{ }^{\circ} \mathrm{C}$ for $30 \mathrm{~min}$ after sieving and steaming. Quality of the dried product was determined by its moisture content. Samples were dried at a temperature of $105{ }^{\circ} \mathrm{C}$ for $3 \mathrm{~h}$ in order to completely evaporate the water. Moisture content in rice bran was $7.65 \%$, which was slightly higher than that obtained by Bhosale and Vijayalakshmi [13], with values of 4.30 and 5.40 for stabilized and probiotic treated rice bran, respectively. Crude fiber, a measurable indigestible cellulose, pentosans, lignin, and other components of this type were in the present samples. The amount of crude fiber in the bran was found at $10.25 \%$. The analysis of ash content in the rice bran samples was simply the burning away of organic content, leaving inorganic minerals. The results showed that ash content of rice bran in this study was found at $6.38 \%$. This value was higher than that obtained by Bhosale and Vijayalakshmi [13], with values of 4.92 and 4.64 for stabilized and probiotic treated rice bran, respectively. This might be due to the difference between untreated and treated rice bran samples.

Table 1 Nutrient composition of rice bran.

\begin{tabular}{cc}
\hline Composition (\%) & Content (\%) \\
\hline Protein (\%) & $12.65 \pm 0.56$ \\
Lipid (\%) & $16.32 \pm 0.81$ \\
Moisture (\%) & $7.65 \pm 0.62$ \\
Fiber (\%) & $10.25 \pm 0.64$ \\
Ash (\%) & $6.38 \pm 0.59$ \\
Carbohydrate* (\%) & 46.75 \\
\hline
\end{tabular}

*By difference

\section{Effect of types of solvents on yield of rice bran oil}

The results of the solvents and extraction period used for rice bran extraction are shown in Table 2. $n$ hexane and ethanol were used as the extraction solvents for comparative study. The extraction temperature used was done at $60{ }^{\circ} \mathrm{C}$. Evidently, $n$-hexane could yield more rice bran oil compared to ethanol $(\mathrm{p}<0.05)$. This was due to the physical properties of rice bran oil with similar chemical characteristics dissolving more in $n$-hexane than ethanol. Even though ethanol is a polar solvent, it is limited in how much it dissolves into a non-polar solute. However, rice bran might show dielectric properties, helping the ability to dissolve in polar solvent. The dielectric properties of grains and seeds vary with moisture content and bulk density, reported by Samuel [15]. When the extraction time increased, yield of rice bran oil also increased, both extracted from both solvents, $n$-hexane and ethanol. It was also found that, during the 12 and $24 \mathrm{~h}$ periods, the yield of rice bran oil extracted by both solvents was not statistically different ( $p \geq 0.05)$. The highest yield was observed by extraction with $n$-hexane during 12 and $24 \mathrm{~h}$. Therefore, the most suitable solvent for the extraction process was $n$-hexane, and the optimum extraction time was $12 \mathrm{~h}$, due to high oil content and less time compared to oil obtained when extraction time was $24 \mathrm{~h}$.

The effects of temperature and time as extraction conditions on rice bran oil yield using $n$-hexane were investigated (Table 3). It revealed that the lowest yield was observed at $50{ }^{\circ} \mathrm{C}$, in comparison with 60 and $70{ }^{\circ} \mathrm{C}$. Yield increased when the extraction time was extended. However, the maximum yield was reached at $12 \mathrm{~h}$ extraction time in both solvents, whereas the maximum extracted temperature at $70{ }^{\circ} \mathrm{C}$ showed no significant difference in the rice bran oil yield extracted at $60{ }^{\circ} \mathrm{C}, \mathrm{p} \geq 0.05$. In addition, a temperature of $60^{\circ} \mathrm{C}$ was the most suitable for oil extraction from rice bran because it saved more energy than using a temperature of $70^{\circ} \mathrm{C}$ in extraction. The maximum yield of rice bran oil was obtained when the extraction period was at $24 \mathrm{~h}$, but there was no significant difference in the oil yield extracted at $12 \mathrm{~h}$ 
http://wjst.wu.ac.th

$(\mathrm{p} \geq 0.05)$. As a result, the most suitable conditions used to extract rice bran were at $60{ }^{\circ} \mathrm{C}$ for $12 \mathrm{~h}$, because they save more energy and time than when the $24 \mathrm{~h}$ extraction time was used.

Table 2 Effect of types of solvents on yield of rice bran oil.

\begin{tabular}{lcc}
\hline Solvent & Extraction time (h) & Yield (\%) \\
\hline$n$-hexane & 1 & $13.02 \pm 0.29^{\mathrm{a}}$ \\
& 3 & $14.87 \pm 0.22^{\mathrm{b}}$ \\
& 6 & $15.50 \pm 0.17^{\mathrm{b}}$ \\
\hline Ethanol & 12 & $16.23 \pm 0.34^{\mathrm{c}}$ \\
& 24 & $16.16 \pm 0.22^{\mathrm{c}}$ \\
\hline & 1 & $12.31 \pm 0.72^{\text {cd }}$ \\
& 3 & $13.51 \pm 0.26^{\mathrm{cd}}$ \\
& 12 & $14.69 \pm 0.21^{\mathrm{d}}$ \\
& 24 & $14.98 \pm 0.37^{\mathrm{e}}$ \\
\end{tabular}

*Data are means of 3 determinations. Mean values followed by different letters within the same column are significantly different $(\mathrm{p}<0.05)$.

Table 3 Effect of extraction condition on yield of rice bran oil.

\begin{tabular}{ccc}
\hline $\begin{array}{c}\text { Extraction temperature } \\
\left.\mathbf{(}^{\mathbf{o}} \mathbf{C}\right)\end{array}$ & $\begin{array}{c}\text { Extraction time } \\
(\mathbf{h})\end{array}$ & Yield (\%) \\
\hline 50 & 1 & $11.37 \pm 0.16^{\mathrm{a}}$ \\
& 3 & $12.59 \pm 0.27^{\mathrm{b}}$ \\
& 6 & $12.76 \pm 0.85^{\mathrm{b}}$ \\
& 12 & $12.93 \pm 0.34^{\mathrm{bc}}$ \\
& 24 & $12.99 \pm 0.29^{\mathrm{bc}}$ \\
\hline 60 & 1 & $13.76 \pm 0.59^{\mathrm{cd}}$ \\
& 3 & $15.08 \pm 0.51^{\mathrm{de}}$ \\
& 6 & $15.60 \pm 0.26^{\mathrm{ef}}$ \\
& 12 & $15.99 \pm 0.21^{\mathrm{efg}}$ \\
& 24 & $16.36 \pm 0.40^{\mathrm{fg}}$ \\
\hline 70 & 1 & $14.48 \pm 0.31^{\mathrm{fgh}}$ \\
& 3 & $15.23 \pm 0.55^{\mathrm{fgh}}$ \\
& 6 & $15.42 \pm 0.65^{\mathrm{fgh}}$ \\
& 12 & $15.82 \pm 0.52^{\mathrm{gh}}$ \\
& 24 & $16.02 \pm 0.73^{\mathrm{h}}$ \\
\hline
\end{tabular}

*Data are means of 3 determinations. Mean values followed by different letters within the same column are significantly different $(\mathrm{p}<0.05)$. 


\section{Effect of storage time on quality of rice bran oil}

The optimized rice bran oil extraction condition, $60{ }^{\circ} \mathrm{C}$ for $12 \mathrm{~h}$, was applied and routinely determined for FFA, peroxide, and saponification value at $0,1,2,4$, and 8 weeks. As a result (Table 4), FFA increased gradually (in the range of $5.66-8.94 \%$ ) and possibly caused rancidity. FFA is produced by the hydrolysis of oils and fats. The level of FFA depends on time, temperature, and moisture content, because the oils and fats are exposed to various environments such as storage, processing, heating, or frying. Since FFA is less stable than neutral oil, it is more prone to oxidation and to be rancid. Thus, FFA is a key feature linked with the quality and commercial value of oils and fats [7]. Rice bran oil is susceptible to oxidation during storage, cooking, or processing, resulting in the formation of primary and secondary oxidation products (aldehyde and ketone), FFA, polar compounds (PC), and other hazardous components, such as trans-fatty acid (TFA) and polycyclic aromatic hydrocarbons (PAH). The presence of FFA in oils may promote oxidation [16]. High levels of FFA, or free acidity, is due to wet harvest conditions, which promote the action of lipases generating these molecules, as well as moist grains during storage [17].

Table 4 Effect of storage time on quality of rice bran oil.

\begin{tabular}{lccccc}
\hline \multirow{2}{*}{ Parameter } & \multicolumn{5}{c}{ Weeks } \\
\cline { 2 - 6 } & $\mathbf{0}$ & $\mathbf{1}$ & $\mathbf{2}$ & $\mathbf{4}$ & $\mathbf{8}$ \\
\hline Free fatty acid (\%) & $5.66 \pm 0.23^{\mathrm{a}}$ & $6.06 \pm 0.16^{\mathrm{a}}$ & $7.23 \pm 0.11^{\mathrm{b}}$ & $7.40 \pm 0.22^{\mathrm{b}}$ & $8.94 \pm 0.60^{\mathrm{c}}$ \\
Peroxide value & $6.59 \pm 0.34^{\mathrm{a}}$ & $6.86 \pm 0.24^{\mathrm{ab}}$ & $7.28 \pm 0.36^{\mathrm{abc}}$ & $7.72 \pm 0.33^{\mathrm{bc}}$ & $8.18 \pm 0.22^{\mathrm{c}}$ \\
Iodine value & $88.51 \pm 1.14^{\mathrm{a}}$ & $87.55 \pm 0.84^{\mathrm{ab}}$ & $86.60 \pm 0.97^{\mathrm{bc}}$ & $90.40 \pm 0.81^{\mathrm{cd}}$ & $88.94 \pm 1.66^{\mathrm{d}}$ \\
\hline
\end{tabular}

* Data are means of 3 determinations. Mean values followed by different letters within the same row are significantly different $(\mathrm{p}<0.05)$.

The peroxide value is defined as the amount of peroxide oxygen per $1 \mathrm{~kg}$ of fat or oil. Detection of peroxide gives the initial evidence of rancidity in unsaturated fats and oils. It gives a measure of the extent to which an oil sample has undergone primary oxidation; the extent of secondary oxidation may be determined from p-anisidine testing. The double bonds found in fats and oils play a role in autoxidation. Oils with a high degree of unsaturation are most susceptible to autoxidation. The best test for autoxidation (oxidative rancidity) is determination of the peroxide value. Peroxides are intermediates in the autoxidation reaction. In this study, peroxide value of rice bran oil was increased when the storage time was increased. The value was in the range of 6.59-8.18. Peroxide values of fresh oils are less than 10 milliequivalents $/ \mathrm{kg}$; when the peroxide value is between 30 and 40 milliequivalents $/ \mathrm{kg}$, a rancid taste is noticeable. Autoxidation is a free radical reaction involving oxygen that leads to deterioration of fats and oils which form off-flavors and off-odors. Peroxide value, concentration of peroxide in an oil or fat, is useful for assessing the extent of spoilage.

The iodine value (or iodine adsorption value, or iodine number, or iodine index) is the mass of iodine in grams that is consumed by $100 \mathrm{~g}$ of a chemical substance. Iodine numbers are often used to determine the amount of unsaturation in fatty acids. This unsaturation is in the form of double bonds, which react with iodine compounds. The higher the iodine number, the more $\mathrm{C}=\mathrm{C}$ bonds are present in the fat. In this study, iodine value was in the range of $88.51-90.40$.

Saponification value represents the number of milligrams of potassium hydroxide required to saponify $1 \mathrm{~g}$ of fat under the conditions specified. It is a measure of the average molecular weight (or chain length) of all the fatty acids present. As most of the mass of a fat/tri-ester is in the 3 fatty acids, the saponification value allows for comparison of the average fatty acid chain length. The long chain fatty acids found in fats have a low saponification value, because they have a relatively fewer number of carboxylic functional groups per unit mass of the fat as compared to short chain fatty acids. If more moles 
of base are required to saponify $\mathrm{N}$ grams of fat, then there are more moles of the fat, and the chain lengths are relatively small.

\section{Conclusions}

To reach the highest yield of RBO extraction, it is advisable to employ $n$-hexane and extract at $60{ }^{\circ} \mathrm{C}$ for $12 \mathrm{~h}$. Change in chemical parameters related to RBO quality on shelf were observed. FFA and peroxide value were found to be increasing during 8 weeks of study, whereas iodine value and saponification value were relatively constant.

\section{Acknowledgements}

The authors would like to thank Prince of Songkla University, Thailand for their support in this study (Grant number AGR580243b).

\section{References}

[1] M Friedman. Rice brans, rice bran oils, and rice hulls: Composition, food and industrial uses, and bioactivities in humans, animals, and cells. J. Agric. Food Chem. 2013; 61, 10626-41.

[2] S Sayasoonthorn, S Kaewrueng and P Patharasathapornkul. Rice bran oil extraction by screw press method: Optimum operating settings, oil extraction level and press cake appearance. Rice Sci. 2012; 19, 75-8.

[3] SAS Chatha, AI Hussain, M Zubair and MK Khosa. Analytical characterization of rice (oryza sativa) bran and bran oil from different agro-ecological regions. Pak. J. Agri. Sci. 2011; 48, 243-9.

[4] MJ Lerma-Gercia, JMH Herrero-Martinez, EF Simo-Alfonso, CRB Mendoca and G Ramis-Ramos. Composition, industrial processing and application of rice bran $\gamma$-oryzanol. Food Chem. 2009; 115, 389-404.

[5] P Loypimai, A Moongngarm and P Chottanom. Impact of stabilization and extraction methods on chemical quality and bioactive compounds of rice bran oil. Emir. J. Food Agric. 2015; 27, 849-56.

[6] NR Lakkakula, M Lima and T Walker. Rice bran stabilization and rice bran oil extraction using ohmic heating. Biores. Technol. 2004; 92, 157-61.

[7] AM Matouk, MM El-Kholy, M El-Sadany and YT Hendawy. Rice bran oil extraction using an expeller machine. Misr. J. Agric. Eng. 2009; 26, 324-42.

[8] WW Huang, W Wang, JL Li and ZH Li. Study on the preparation process of rice bran oil by the ultrasonic enzymatic extraction. Adv. J. Food Sci. Technol. 2013; 5, 213-6.

[9] BMWPK Amarasinghe, MPM Kumarasiri and NC Gangodavilage. Effect of method of stabilization on aqueous extraction of rice bran oil. Food Bioprod. Process. 2009; 87, 108-14.

[10] E Uquiche, M Jerez and J Ortiz. Effect of pretreatment with microwaves on mechanical extraction yield and quality of vegetable oil from Chilean hazelnuts (Gevuina avellana Mol). Innov. Food Sci. Emerg. Technol. 2008; 9, 495-500.

[11] AOAC. Approved methods of the American Association of Cereal Chemists. $16^{\text {th }}$ ed. St. Paul, Minnesota, 1995.

[12] AOCS. Official method and recommended practices of the AQCS. $4^{\text {th }}$ ed. Champaign, Illinois, 1998.

[13] S Bhosale and D Vijayalakshmi. Processing and nutritional composition of rice bran. Curr. Res. Nutr. Food Sci. 2015; 3, 74-80.

[14] RM Saunders. Rice bran: Composition and potential food uses. Food Rev. Int. 1985; 1, 465-95.

[15] ST Wara, A Abayomi-Alli and AO Salau. Evaluation of the dielectric properties of local cereals in the audio frequency range. In: Proceedings of the $5^{\text {th }}$ IEEE International Conference on Signal Processing, Computing and Control, Solan, India. 2019, p. 313-8.

[16] N Frega, M Mozzon and G Lercker. Effects of free fatty acids on oxidative stability of vegetable oil. J. Am. Oil Chem. Soc. 1999; 76, 325-9.

[17] C Beratlief and H Iliescu. Highlights of proper sunflower seed storage. Helia 1998; 20, 121-32. 